\title{
RECURRENT VENTRICULAR TACHYCARDIA ASSOCIATED WITH GANGRENE
}

\author{
Richard M. Forster and Dennis T. Mangano
}

\begin{abstract}
Ventricular tachycardia occurs with myocardial ischaemia, hypoxia, hypercarbia, hypokalaemia, and digitalis toxicity. We report recurrent ventricular tachycardia occurring in a patient with gangrene of the lower extremities in whom none of the common aetiologies for dysrhythmia could be demonstrated. Ventricular tachycardia stopped and did not recur after amputation. This course leads us to speculate that release of a toxic substance from gangrenous tissue may contribute to the development of ventricular tachycardia.
\end{abstract}

Key WORDS: CompliCations, heart, dysthythmia; Gangrene.

\section{CASE REPORT}

A 62-YEAR-OLD MAN with a history of transitional cell carcinoma of the bladder was admitted to the Reno Veterans Administration Hospital with haematuria, dysuria, and frequency. His history also included an old inferior wall myocardial infarction, cardiomegaly with prior episodes of congestive heart failure, peripheral vascular disease, and a 50 pack-year history of cigarette smoking. The patient's condition was stable until three weeks after admission, at which time congestive heart failure and atrial fibrillation developed. These conditions resolved with the administration of digoxin and furosemide (Lasix ${ }^{\circledR}$ ).

The following day both lower extremities were cool and cyanotic. No femoral or popliteal pulses could be felt. Heparin was administered at a rate of 100 units $/ \mathrm{hr}$. Pneumonia of the right lower lobe developed, and during the next four days the patient was treated with trimethoprim sulfamethoxazole $\left(\right.$ Bactrim $\left.^{8}\right)$ and cefazolin sodium (Ancef ${ }^{\text {B }}$ ). Circulation remained stable for the following three days and the heart sustained a regular sinus rhythm with a rate of $80-110 / \mathrm{min}$. However the gangrene progressed bilaterally to the level of the knees. At this time ventricular

R.M. Forster, M.D., Resident; D.T. Mangano, Ph.D., M.D., Assistant Professor, Department of Anaesthesia, Veterans Administration Medical Center, University of California, San Francisco, California 94143 , U.S.A.

Reprint requests to: Dr. D.T. Mangano, Department of Anaesthesia (129), Veterans Administration Medical Center, Room 3C-14, Bldg. 203, 4150 Clement Street, San Francisco, California 94121, U.S.A.

Can. Anaesth. Soc. J., vol. 29, no. 1, January 1982 tachycardia appeared and was converted to a normal sinus rhythm by a precordial thump. Intravenous lidocaine infusion was started at a rate of $2 \mathrm{mg} / \mathrm{min}$. The patient was transferred to San Francisco Veterans Administration Medical Center for amputation of the lower extremities. During transport the patient had a second episode of ventricular tachycardia, which was treated with $100 \mathrm{mg}$ of lidocaine.

On admission, physical examination revealed an elderly man who was oriented and responding in a normal fashion. His arterial blood pressure was $14.63 / 9.31 \mathrm{kPa}$ (110/70 torr), pulse rate $72 /$ min (irregularly irregular), respiratory rate $24 \mathrm{breaths} / \mathrm{min}$ (mildly laboured), and temperature $38.3^{\circ} \mathrm{C}$. Physical examination revealed cardiomegaly without other signs of congestive heart failure and marked hypoperfusion of the lower extremities. At this time medication included digoxin, furosemide, potassium chloride, trimethoprim sulfamethoxazole $\left(\right.$ Bactrim $\left.^{\circledR}\right)$, cefazolin sodium(Ance ${ }^{\circledR}$ ), lidocaine and heparin. The electrocardiogram showed atrial fibrillation with a ventricular rate of $72 / \mathrm{min}$ and an old inferior wall myocardial infarction. The chest roentgenogram showed a right lower-lobe infiltrate and left ventricular prominence. Serum potassium was $3.8 \mathrm{mmol} / 1$ and partial thromboplastin time 46 seconds. Serum sodium and calcium were within normal limits. While breathing room-air, the patient had $\mathrm{Pa}_{\mathrm{O}_{2}}$ of $5.05 \mathrm{kPa}$ (38 torr), $\mathrm{Pa}_{\mathrm{CO}_{2}}$ of $3.72 \mathrm{kPa}$, (28 torr), $\left[\mathrm{H}^{+}\right]_{\mathrm{a}} 33.88 \mathrm{nmol} / 1(\mathrm{pH} 7.47)$ and base deficit of $1.0 \mathrm{mmol} / \mathrm{l}$.

Because of the two episodes of unexplained ventricular tachycardia, surgery was delayed. The patient was given supplemental oxygen, 
furosemide, and potassium chloride, $20 \mathrm{mmol} /$ $\mathrm{hr}$. Further doses of digoxin were withheld until his current blood level of digoxin could be determined. Over the next four hours spontaneous ventricular tachycardia occurred twice. These episodes were treated with lidocaine, procainamide, and DC cardioversion using 400 wattssec. The central venous pressure was $0.53 \mathrm{kPa}$ (4 torr). Four hours after admission the digoxin level was $0.8 \mathrm{ng} / \mathrm{ml}$ (nommal, 0.8 to $2.0 \mathrm{ng} / \mathrm{ml}$ ), serum potassium $4.1 \mathrm{mmol} / 1$ and $\mathrm{Pa}_{\mathrm{O}_{2}} 11.3 \mathrm{kPa}$ (85 torr) $\left(\mathrm{F}_{\mathrm{L}_{2}}=0.5\right.$ ). Except for recurrent episodes of ventricular tachycardia, no evidence of ischaemia (e.g., angina, electrocardiographic abnormalities, or haemodynamic instability) was present. Although the cause of these episodes was unknown, we believed they were related to the release of toxins from the gangrenous lower extremities, and that amputation might improve the cardiac status. The patient was taken to the operating room for amputation.

A subarachnoid block was established with $10 \mathrm{mg}$ of tetracaine 1.0 percent diluted to $0.5 \mathrm{per}$ cent with five per cent glucose in distilled water. No epinephrine was used. The sensory level of the block was at $\mathrm{T}_{10}$. Arterial blood pressure and heart rate remained stable at $17.29 / 9.31 \mathrm{kPa}$ (130/70 torr) and 72 beats/min, respectively. During and following the administration of the block, the patient breathed 100 per cent oxygen by face mask. No other medication was administered. Fifteen minutes after incision, unifocal and then multifocal premature ventricular contractions were noted on the electrocardiogram (modified $\mathrm{V}_{5}$ ). Ventricular tachycardia occurred, and DC cardioversion ( 400 watts-sec) was applied. The infusion rate of lidocaine was increased to $4 \mathrm{mg} / \mathrm{min}$. Following cardioversion, blood pressure was $12 / 8 \mathrm{kPa}$ (90/60 torr), pulse rate was $54 / \mathrm{min}$ and regular, and no signs of ischaemia were present in the electrocardiogram. Over the next 30 minutes, approximately fifteen episodes of ventricular tachycardia occurred. These responded to either a precordial thump or DC cardioversion. However, haemodynamic stability decreased, in spite of support with different combinations of lidocaine, procainamide, isoproterenol, dopamine, sodium bicarbonate, and phenylephrine. Systolic blood pressure between episodes varied betweeen 8 and $12 \mathrm{kPa}$ (60 and 90 torr), and sinus rhythm was $40-50 / \mathrm{min}$. Arterial oxygen tension was $21.3 \mathrm{kPa}$ (160 torr), $\mathrm{Pa}_{\mathrm{CO}_{2}} 3.72 \mathrm{kPa}$ (28 torr), $\left.\left[\mathrm{H}^{+}\right] \mathrm{a} 36.31 \mathrm{nmol} / / \mathrm{pH} 7.44\right)$ base deficit $3.5 \mathrm{mmol} / 1$ and serum potassium $4.0 \mathrm{mmol} / 1$. At this time the patient became progressively disoriented and tracheal intubation was done, facilitated by the intravenous administration of succinylcholine $100 \mathrm{mg}$. Ventilation was controlled with $\mathrm{Fi}_{\mathrm{O}_{2}} 1.0$ and arterial blood gases remained satisfactory. Ventricular tachycardia continued to occur approximately every two minutes and was treated as described previously.

The right and left legs were then amputated (below and above the knees, respectively). Approximately two minutes later, before the final sutures were placed, ventricular tachycardia stopped abruptly. During closure and dressing of the wound, the patient was haemodynamically stable. Blood pressure was $12 / 8 \mathrm{kPa}$ (90/60 torr) and heart rate was 54 /minute (regular sinus rhythm). No signs of ischaemia were present. The circulatory status remained stable during the night, throughout which a lidocaine infusion $(2 \mathrm{mg} / \mathrm{min})$ was given. No signs of ventricular irritability occurred. The tracheal tube was removed the next morning and the lidocaine infusion was discontinued. No further episodes of ventricular irritability occurred. Subsequent electrocardiogram and myocardial CPK bands did not suggest myocardial infarction.

\section{Discussion}

Dysrhythmia is not uncommon during operation. ${ }^{1,2}$ However serious dysrhythmia accompanied by marked decrease in perfusion is relatively rare. ${ }^{3}$ The more common causes of dysrhythmia are hypercarbia, hypoxia, hypokalaemia, and digitalis toxicity. In the case reported each of these possible causes was considered and either eliminated or corrected, but ventricular tachycardia continued to occur. Only with the amputation of the gangrenous extremities did the dysrhythmia cease - abruptly and without recurrence. Thus we conjecture that ventricular tachycardia may be related to the presence of gangrenous tissue.

Several discussions ${ }^{4,6}$ have suggested that gangrenous tissue may release "toxins" that could affect the myocardium. The potential "toxins" include catecholamines, calcium, gram-negative bacillery by-products, products of altered glucose kinetics, and disorders of prostaglandin metabolism. ${ }^{4,6}$ However no specific "toxin" has been demonstrated, nor has a causal relationship between dysrhythmia and gangrenous tissue been shown previously. Ideally demonstration of such a causal relation- 
ship would proceed in three stage: (1) presence of dysrhythmia when gangrenous tissue was in contact with the circulation; (2) suppression of dysrhythmia when that contact was interrupted; and (3) return of dysrhythmia when contact was reestablished. In addition, during these stages other factors which might contribute to dysrhythmia would have to remain unchanged. Thus the events of the present case do not fully demonstrate a causal relationship, but they do suggest that such a relationship existed in this patient. Refractory ventricular tachycardia persisted for hours despite the therapeutic measures described above. The immediate and permaneft resolution of dysrhythmia after amputation suggests to us that the presence of gangrenous tissue played a causal role. The specific mechanism, however, is uncertain. None of the findings before or after operation (temperature, calcium level, tissue enzyme analysis) has led us to postulate an underlying mechanism.

\section{REFERENCES}

1. LapPas, D.G., Powell, W.M.J. JR. \& DAGGETT, W.M. Cardiac dysfunction in the preoperative period: pathophysiology, diagnosis, and treatment. Anesthesiology 47: 117 (1977).

2. KaTZ, R.L. \& BigGER, J.T. JR. Cardiac arrhythmias during anesthesia and operation. Anesthesiology 33: 193 (1970).

3. WYNANDS, J.E. Amhythmias in the operating room. In ASA Refresher Courses in Anesthesiology, Vol. 6, pp. 199-213. Philadelphia: J.B. Lippincott (1978).

4. LABrosse, E.H. \& Cowley, R.A. Tissue levels of catecholamines in patients with different types of trauma. J. Trauma 13:61 (1973).

5. Wilmore, D.W., Mason, A.D. \& Pruitt, B.A. $J_{R}$. Alterations in glucose kinetics following thermal injury. Surg. Forum 26: 81 (1975).

6. Cuthrertson, D. \& Tulstone, W.J. Metabolism during the postinjury period. Adv. Clin. Chem. 12: i (1969).

RÉSUMÉ

L'ischémie du myocarde, l'hypoxie, l'hypercarbie, l'hypopotassémie et la toxicité digitalique sont des causes bien établies de tachycardie ventriculaire. Nous rapportons ici un cas de tachycardie ventriculaire à répétition chez un patient présentant une gangrène des deux jambes. Aucun des facteurs mentionnés plus haut n'a pu être mis en cause comme facteur déclenchant chez ce patient. Les épisodes de tachycardie ont cessé pour ne plus réapparaître dès que l'amputation des deux jambes a été complétée. Nous émettons l'hypothèse d'une substance toxique produite par le tissu gangréneux, substance qui pourrait contribuer à déclencher des tachycardies ventriculaires. 